\title{
Drug Export Activity of the Human Canalicular Multispecific Organic Anion Transporter in Polarized Kidney MDCK Cells Expressing cMOAT (MRP2) cDNA
}

\author{
Raymond Evers, ${ }^{*}$ Marcel Kool, ${ }^{*}$ Liesbeth van Deemter, ${ }^{*}$ Hans Janssen, ${ }^{\ddagger}$ Jero Calafat, ${ }^{\ddagger}$ Lauran C.J.M. Oomen, ${ }^{\ddagger}$ \\ Coen C. Paulusma, ${ }^{\S}$ Ronald P.J. Oude Elferink, ${ }^{\S}$ Frank Baas, ${ }^{\|}$Alfred H. Schinkel, ${ }^{\star}$ and Piet Borst ${ }^{\star}$ \\ $*$ Division of Molecular Biology, and ${ }^{\ddagger}$ Division of Cell Biology, The Netherlands Cancer Institute, Plesmanlaan 121, 1066 CX Amsterdam, \\ The Netherlands; and ${ }^{\S}$ Department of Gastroenterology, and ${ }^{\|}$Department of Neurology, Academic Medical Center, 1105 AZ Amsterdam, \\ The Netherlands
}

\begin{abstract}
The canalicular (apical) membrane of the hepatocyte contains an ATP-dependent transport system for organic anions, known as the multispecific organic anion transporter (cMOAT). The deduced amino acid sequence of cMOAT is $49 \%$ identical to that of the human multidrug resistanceassociated protein (MRP) MRP1, and cMOAT and MRP1 are members of the same sub-family of adenine nucleotide binding cassette transporters. In contrast to MRP1, cMOAT was predominantly found intracellularly in nonpolarized cells, suggesting that cMOAT requires a polarized cell for plasma membrane routing. Therefore, we expressed $c M O A T$ cDNA in polarized kidney epithelial MDCK cell lines. When these cells are grown in a monolayer, cMOAT localizes to the apical plasma membrane. We demonstrate that cMOAT causes transport of the organic anions $S$-(2,4-dinitrophenyl)glutathione, the glutathione conjugate of ethacrynic acid, and $S$-( $\left.\mathrm{PGA}_{1}\right)$-glutathione, a substrate not shown to be transported by organic anion transporters previously. Transport is inhibited only inefficiently by compounds known to block MRP1. We also show that cMOAT causes transport of the anticancer drug vinblastine to the apical side of a cell monolayer. We conclude that cMOAT is a 5'-adenosine triphosphate binding cassette transporter that potentially might be involved in drug resistance in mammalian cells. (J. Clin. Invest. 1998. 101:1310-1319.) Key words: cMOAT • drug resistance $\bullet$ glutathione $S$-conjugate $\bullet \mathrm{MRP} \bullet$ routing
\end{abstract}

\section{Introduction}

Membrane proteins belonging to the ATP-binding cassette $(\mathrm{ABC})^{1}$ family of transport proteins play a central role in the defense of prokaryotic and eukaryotic cells against toxic compounds (1-3). This is illustrated by multidrug resistant (MDR)

Address correspondence to Piet Borst, The Netherlands Cancer Institute, Antoni Van Leeuwenhoek Huis, Division of Molecular Biology, Plesmanlaan 121, 1066 CX Amsterdam, The Netherlands. Phone: 3120-512-2880; FAX: 31-20-669-1383. Alfred H. Schinkel's current address is Division of Experimental Therapy, The Netherlands Cancer Institute, Plesmanlaan 121, 1066 CX Amsterdam, The Netherlands.

Received for publication 16 June 1997 and accepted in revised form 26 January 1998.

J. Clin. Invest.

(C) The American Society for Clinical Investigation, Inc. 0021-9738/98/04/1310/10 \$2.00

Volume 101, Number 7, April 1998, 1310-1319

http://www.jci.org cells, resistant against a range of drugs with different cellular targets. Thus far, two members of the ABC-transporter family have been identified that render human cancer cells MDR: the MDR1 P-glycoprotein (Pgp) and the multidrug resistanceassociated protein (MRP1; for review see references 4-6). Both were discovered through their overexpression in MDR tumor cell lines and both confer resistance by decreasing the intracellular concentration of cytotoxic drugs.

Whereas Pgp transports substrates in an unmodified form, $M R P 1$ overexpression is associated with an increased ATPdependent glutathione $S$-conjugate transport activity $(7,8)$. Experiments with inside-out membrane vesicles indicated that MRP1 is able to transport a range of substrates that are conjugated to glutathione (GSH), glucuronide, or sulfate (9-13). Transporters with these characteristics are known as GS-X pumps (14), multispecific organic anion transporters (MOAT; 15 ), or leukotriene $\mathrm{C}_{4}\left(\mathrm{LTC}_{4}\right)$ transporters (16).

$M R P 1$ expression is found in all major organs analyzed and in all cell types from peripheral blood $(17,18)$. Expression of MRP1 in the liver is low $(17,19)$ and the protein was found in the lateral membranes of hepatocytes (20). Lateral localization of MRP1 was also observed in polarized pig kidney cells stably transfected with MRP1 cDNA (21). It is known, however, that the canalicular membrane of the hepatocyte contains a relatively high ATP-dependent transport activity for organic anions $(22,23)$. This activity is known as the canalicular multispecific organic anion transporter (cMOAT). Comparison of mutant rats $\left(\mathrm{TR}^{-} / \mathrm{GY}\right)$ lacking this transport activity with wildtype rats has shown that cMOAT, like MRP1, transports a wide range of glutathione, glucuronate, and sulphate conjugates (for review see reference 24). Recently, several groups cloned the cDNA encoding rat cmoat (also called mrp2; references 25-27). Immunostaining revealed that cmoat is predominantly present in the hepatocanalicular membrane. In the $\mathrm{TR}^{-}$ rat, a single-nucleotide deletion in cmoat resulted in a frame shift, reduced mRNA level, and absence of the protein (25). Transient transfection of cmoat cDNA in COS cells resulted in export of $S$-(2,4-dinitrophenyl)-glutathione (DNP-GS) out of the cell, confirming that cmoat causes organic anion transport (reference 28; Paulusma, C.C., and R.P.J. Oude Elferink, unpublished results).

We and others recently cloned human $c M O A T$ cDNA (29, $30)$. The deduced amino acid sequence showed $78 \%$ identity with rat cmoat and $49 \%$ with human MRP1, respectively. Hu-

1. Abbreviations used in this paper: $\mathrm{ABC}, 5^{\prime}$-ATP-binding cassette; CDNB, 1-chloro-2,4 dinitrobenzene; cMOAT, canalicular multispecific organic anion transporter; CMV, cytomegalovirus; DNP-GS, dinitrophenyl glutathione; EA-GS, ethacrynic acid glutathione; GSH, glutathione; GST, glutathione $S$-transferase; MDR, multidrug resistance; MRP, MDR-associated protein; Pgp, P-glycoprotein. 
man cMOAT, like rat cmoat, is mainly present in the liver (30, 31). Attempts to functionally characterize cMOAT in several nonpolarized cells were hampered by the fact that the protein was mainly found intracellularly and not in the plasma membrane (our unpublished results), suggesting that cMOAT requires a polarized cell for plasma membrane routing. We have shown before that the expression of cDNAs for other transporters in polarized cells yields valuable information about the transport characteristics of these proteins $(21,32,33)$. To study whether expression of $c M O A T$ cDNA in a polarized cell line results in an active transporter we have transduced polarized Madin-Darby Canine Kidney (MDCK) cells with a retrovirus containing $c M O A T$ cDNA. We describe here that cMOAT is present in the apical plasma membrane of the transduced MDCK cells, where its presence causes transport of several glutathione $S$-conjugates and the anticancer drug vinblastine.

\section{Methods}

Materials. $\left[{ }^{14} \mathrm{C}\right]-1$-chloro-2,4-dinitrobenzene $\left(\left[{ }^{14} \mathrm{C}\right] \mathrm{CDNB} ; 10 \mathrm{Ci} / \mathrm{mol}\right)$, $\left[{ }^{3} \mathrm{H}\right]$ daunorubicin $(4 \mathrm{Ci} / \mathrm{mmol})$, inulin- $\left[{ }^{14} \mathrm{C}\right]$ carboxylic acid $(5.95 \mathrm{Ci} /$ mol, molecular mass $\sim 5,200[\mathrm{~g} / \mathrm{mol}]),\left[{ }^{3} \mathrm{H}\right]$ vinblastine $(12 \mathrm{Ci} / \mathrm{mol}$, $\left[5,6(\mathrm{n})-{ }^{3} \mathrm{H}\right]$ Prostaglandin $\mathrm{E}_{1}\left(\mathrm{PGE}_{1} ; 43 \mathrm{Ci} / \mathrm{mmol}\right)$, and $\left[{ }^{14} \mathrm{C}\right] \mathrm{Eth}-$ acrynic acid $(15 \mathrm{Ci} / \mathrm{mol})$ were obtained from Amersham International (Little Chalfont, UK). Dinitrophenyl[glycine- $\left.2-{ }^{3} \mathrm{H}\right]$ glutathione (DNP- $\left[{ }^{3} \mathrm{H}\right] \mathrm{GS} ; 1 \mathrm{Ci} / \mathrm{mol}$ ) was prepared as described (34). The radioactive conjugate of EA (2, 3-dichloro-4-[2-methylene-1-1-oxobutyl]phenoxylacetic acid) was synthesized from $\left[{ }^{14} \mathrm{C}\right] \mathrm{EA}$ and glutathione as described $(35,36) \cdot\left[{ }^{3} \mathrm{H}\right] \mathrm{PGA}_{1}$ was freshly prepared from $\left[{ }^{3} \mathrm{H}\right] \mathrm{PGE}_{1}$ by acid-catalyzed dehydration in water-acetic acid- $85 \%$ orthophosphoric acid (10:3:2) as described previously (37). After dehydration the incubation mixture was extracted with ethyl acetate, vacuum dried, and dissolved in ethanol (96\%). Other chemicals and drugs were from Sigma Chemical Co. (St. Louis, MO).

Cell lines. The kidney-derived MDCK cell clones strain I (MDCKI; reference 38) and strain II (MDCKII; reference 39) were cultured in DME with $10 \%$ FCS. A HindIII-NcoI DNA fragment containing the complete predicted $c M O A T$ open reading frame (GenBank accession number U49248; reference 30) was inserted in the retroviral vector (pCMV)-neo (40), resulting in pCMV-cMOAT. The retroviral packaging cell line Phoenix (kindly provided by G.P. Nolan, Stanford University Medical Center, Stanford, CA; reference 41) was cultured in Iscoves medium with $10 \%$ FCS. Cells were transfected using the calcium phosphate coprecipitation protocol using a transfection kit (GIBCO BRL, Gaithersburg, MD). At $16 \mathrm{~h}$ after transfection, the medium was changed and growth was continued for $24 \mathrm{~h}$. Cells were seeded at a dilution of $1 / 10$ and the next day the virus containing supernatant was collected and frozen at $-20^{\circ} \mathrm{C}$. For transduction of MDCK cell lines, $2 \times 10^{6}$ cells were incubated with a $5 \mathrm{ml} 1 / 10$ diluted virus stock containing $30 \mu \mathrm{g}$ Transfection Reagent (DOTAP; Boehringer Mannheim, Mannheim, Germany). After $10 \mathrm{~h}$, the medium was changed and fresh medium was added. $48 \mathrm{~h}$ after infection cells were trypsinized and seeded at dilutions from 1/4-1/64. Stably transduced cells were selected for 2-3 wk in medium with G-418 at 800 $\mu \mathrm{g} / \mathrm{ml}$.

Immunocytochemistry. Cells were grown on microporous polycarbonate membrane filters ( $3 \mu \mathrm{m}$ pore size, $24.5 \mathrm{~mm}$ diameter, Transwell $^{\mathrm{TM}} 3414$; Costar Corp., Cambridge, MA) at a density of $2 \times 10^{6}$ cells per well as described previously (21). For confocal laser scanning microscopy, cells were washed in PBS and fixed for $10 \mathrm{~min}$ in $3 \%$ (vol/vol) formaldehyde in PBS at room temperature, followed by permeabilization with $1 \%(\mathrm{vol} / \mathrm{vol})$ Triton $\mathrm{X}-100$ for $5 \mathrm{~min}$. Filters were incubated with $\mathrm{mAb} \mathrm{M}_{2}$-III-6 (undiluted; reference 25) for $60 \mathrm{~min}$ at room temperature. Antibody binding was detected with a FITClabeled sheep anti-mouse IgG (1:50; Boehringer Mannheim). Filters were mounted with Vectashield (Vector Laboratories, Inc., Burlin- game, CA) containing propidium iodide $(1 \mu \mathrm{g} / \mathrm{ml})$ for counterstaining of nucleic acids. Cells were examined with a MRC-600 confocal microscope (Bio-Rad, Hertfordshire, UK), coupled to a Nikon microscope equipped with a $\times 60$ objective. For immunoelectron microscopy, cells were grown on plastic and fixed in a mixture of $4 \%$ (wt/ vol) paraformaldehyde and $0.5 \%$ ( vol/vol) glutaraldehyde in $0.1 \mathrm{M}$ phosphate buffer ( $\mathrm{pH}$ 7.2). Cells were scraped from plastic and embedded in $10 \%(\mathrm{wt} / \mathrm{vol})$ gelatin in PBS. Ultrathin frozen sections were incubated with $\mathrm{mAb} \mathrm{M}_{2}$-III-6 (undiluted), followed by rabbit anti-mouse $\operatorname{IgG}(1: 40)$ and goat anti-rabbit $\operatorname{IgG}(1: 40)$ linked to 10 $\mathrm{nm}$ gold particles (Amersham, Den Bosch, The Netherlands). Incubations were for $1 \mathrm{~h}$ at room temperature. After immunolabeling, the cryosections were embedded in methylcellulose/uranylacetate and examined with a Philips CM10 electron microscope (Philips, Eindhoven, The Netherlands).

Transport assays. Export of $\left[{ }^{14} \mathrm{C}\right] \mathrm{DNP}-\mathrm{GS}$ (dinitrophenyl GSH) from cells was determined by incubating cells with $\left[{ }^{14} \mathrm{C}\right] \mathrm{CDNB}$ as described previously (21). Briefly, cells were grown on polycarbonate filters (see immunocytochemistry; $12 \mathrm{~mm}$ diameter filters were used for the experiment described in Table III) for 3-4 days. $2 \mathrm{ml}$ of medium (room temperature) containing $2 \mu \mathrm{M}\left[{ }^{14} \mathrm{C}\right] \mathrm{CDNB}$ was applied to both the apical and basal compartment of the monolayer and 200$\mu \mathrm{l}$ aliquots were taken at various time points. After extraction with $200 \mu$ of ethyl acetate to remove $\left[{ }^{14} \mathrm{C}\right] \mathrm{CDNB}$ not converted into $\left[{ }^{14} \mathrm{C}\right] \mathrm{DNP}-\mathrm{GS}$, radioactivity in $160 \mu \mathrm{l}$ of the water phase was determined by liquid scintillation counting. The amount of radioactivity was corrected for the decrease in volume of culture medium. To determine intracellular radioactivity, cells were washed with cold PBS, filters were cut from the plate and counted directly in liquid scintillation fluid. We have shown before that $70-90 \%$ of radioactivity directly measured in cells on filters was extractable $\left[{ }^{14} \mathrm{C}\right] \mathrm{DNP}-\mathrm{GS}(21)$. In case inhibitors were used during the incubation period, cells were first incubated with medium containing inhibitor at $37^{\circ} \mathrm{C}$ in $5 \% \mathrm{CO}_{2}$ for $10 \mathrm{~min}$ before adding substrate.

Export of $\left[{ }^{3} \mathrm{H}\right] \mathrm{PGA}_{1}$-GS was determined by washing cells in HBSS (5.6 mM glucose, $10 \mathrm{mM}$ Hepes, $5.4 \mathrm{mM} \mathrm{KCl}, 143 \mathrm{mM} \mathrm{NaCl}$, $1.3 \mathrm{mM} \mathrm{CaCl}_{2}, 0.4 \mathrm{mM} \mathrm{MgSO}_{4}, 0.5 \mathrm{mM} \mathrm{MgCl}_{2}, 0.42 \mathrm{mM} \mathrm{NaHCO}_{3}$, $0.44 \mathrm{mM} \mathrm{KH}_{2} \mathrm{PO}_{4}, 0.34 \mathrm{mM} \mathrm{Na}_{2} \mathrm{HPO}_{4}, \mathrm{pH}$ 7.4). 2 ml HBSS containing $1 \mu \mathrm{M}\left[{ }^{3} \mathrm{H}\right] \mathrm{PGA}_{1}$ was added to both sides of the monolayer and cells were incubated at $37^{\circ} \mathrm{C}$. Samples $(200 \mu \mathrm{l})$ were taken after various time points and extracted twice with an equal volume of ethyl acetate. Sample analyses were as for $\left[{ }^{14} \mathrm{C}\right] \mathrm{DNP}-\mathrm{GS}$. In case samples were acidified with $2 \%$ formic acid before extraction as described previously (42), essentially the same results were obtained as without acidification.

$\left[{ }^{3} \mathrm{H}\right]$ Daunorubicin and $\left[{ }^{3} \mathrm{H}\right]$ vinblastine transport assays were carried out exactly as described $(21,32)$. Cells were seeded on microporous polycarbonate membrane filters (see above). The experiment was started $(\mathrm{t}=0)$ by replacing the medium at either the apical or the basal side of the cell layer with $2 \mathrm{ml}$ of complete medium containing $2 \mu \mathrm{M}$ of drug (at $0.25 \mu \mathrm{Ci} / \mathrm{ml})$, and $\left[{ }^{14} \mathrm{C}\right]$-labeled inulin $(0.025$ $\mu \mathrm{Ci} / \mathrm{ml}, 4.2 \mu \mathrm{M})$. The cells were incubated at $37^{\circ} \mathrm{C}$ in $5 \% \mathrm{CO}_{2}$ and 50 $\mu \mathrm{l}$ aliquots were taken from each compartment at various time points. Radioactivity was measured as the fraction of total radioactivity added at the beginning of the experiment. The paracellular flux was monitored by the appearance of inulin $\left[{ }^{14} \mathrm{C}\right]$ carboxylic acid in the opposite compartment.

Preparation of membrane vesicles and vesicle uptake studies. Cells from 20 tissue culture dishes (diameter $15 \mathrm{~cm}$ ) were washed in PBS and incubated for $1 \mathrm{~h}$ in Cell Dissociation Solution (a nonenzymatic formulation for dislodging cells from plastic; Sigma Chemical Co.) at $37^{\circ} \mathrm{C}$. After collecting the cells they were harvested by centrifugation at $180 \mathrm{~g}$ for $5 \mathrm{~min}$ at $4^{\circ} \mathrm{C}$, and washed twice in ice-cold PBS. The pellet was diluted in $30 \mathrm{ml}$ hypotonic buffer $(250 \mathrm{mM}$ mannitol, $20 \mathrm{mM}$ Tris/Hepes pH 7.4, $1 \mathrm{mM}$ PMSF, leupeptin, aprotinin, pepstatin $[1 \mu \mathrm{g} / \mathrm{ml} \mathrm{each}]$ ), and incubated for $30 \mathrm{~min}$ in the presence of $250 \mathrm{U}$ of Benzonase (Merck USA, Hawthorne, NY) on ice. The cell lysate was homogenized with a Dounce B homogenizer (glass/glass, tight 


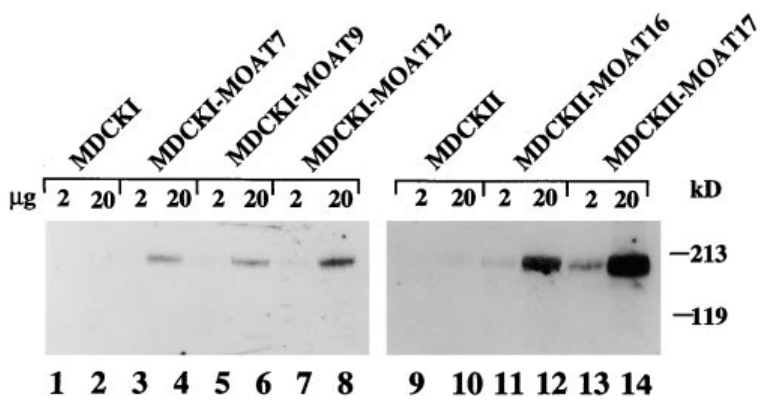

Figure 1. Western blot with total cell lysates from MDCKI and MDCKII derived clones. 2 and $20 \mu \mathrm{g}$ of protein was size fractionated in a $7.5 \%$ polyacrylamide gel containing $0.1 \%(\mathrm{wt} / \mathrm{vol})$ SDS. After electroblotting, cMOAT was visualized by staining with $\mathrm{mAb}_{2}$-III6. Protein-antibody interaction was detected using the enhanced chemiluminescence technique. The identity of the cell lines analyzed is indicated over the lanes.

pestle, 50 strokes) and centrifuged at $2,000 \mathrm{~g}$ for $10 \mathrm{~min}$ at $4^{\circ} \mathrm{C}$. The supernatant containing the crude membrane fraction was layered on top of a $38 \%$ (wt/vol) sucrose solution in $20 \mathrm{mM}$ Tris/Hepes (pH 7.4), $1 \mathrm{mM}$ EDTA and centrifuged in a Beckman SW41 rotor at $150.000 \mathrm{~g}$ for $2 \mathrm{~h}$ at $4^{\circ} \mathrm{C}$. The turbid layer at the interphase was collected, diluted to $13 \mathrm{ml}$ with TS buffer ( $10 \mathrm{mM}$ Tris- $\mathrm{Cl}$ [pH 7.4], $250 \mathrm{mM}$ sucrose), and centrifuged at $150.000 \mathrm{~g}$ for $30 \mathrm{~min}$ at $4^{\circ} \mathrm{C}$. The resulting pellet was suspended in $300 \mu \mathrm{l}$ of TS buffer, and vesicles were formed by passing the suspension 30 times through a 25 -gauge needle with a syringe. Vesicles were frozen in liquid nitrogen and stored at $-80^{\circ} \mathrm{C}$.

Transport of DNP- $\left[{ }^{3} \mathrm{H}\right] \mathrm{GS}$ and $\left[{ }^{14} \mathrm{C}\right]$ ethacrynic acid glutathione (EA-GS) was measured by the rapid filtration technique using nitrocellulose filters $(0.45 \mu \mathrm{m}$ pore size; Schleicher \& Schuell, Inc., Keene, $\mathrm{NH})$ presoaked in TS buffer $(8,13)$. The reaction buffer was TS supplemented with $4 \mathrm{mM}$ ATP, $10 \mathrm{mM} \mathrm{MgCl}_{2}, 10 \mathrm{mM}$ creatine phosphate, $100 \mu \mathrm{g}$ creatine kinase per $\mathrm{ml}$, and the indicated amount of substrate. Vesicles (20 $\mu \mathrm{g}$ of protein) were rapidly thawed and added to the reaction mixture in a total volume of $110 \mu \mathrm{l}$ at $30^{\circ} \mathrm{C}$ with $\left[{ }^{14} \mathrm{C}\right]$ EA-GS or at $37^{\circ} \mathrm{C}$ with DNP- $\left[{ }^{3} \mathrm{H}\right] \mathrm{GS}$ as the substrate, respectively. Samples of $20 \mu \mathrm{l}$ were taken at the indicated time points, directly applied to the membrane filters, and rinsed with $5 \mathrm{ml}$ of icecold TS buffer. Filters were placed in liquid scintillation fluid, and radioactivity was measured by liquid scintillation counting.

\section{Results}

Generation of MDCK cells expressing human cMOAT. To make stable $c M O A T$ expressing clones in MDCK cells we cloned the cMOAT cDNA behind the CMV promoter in the retroviral vector pCMV-neo, which contains the bacterial neo gene for selection with G-418 (40). pCMV-cMOAT was transfected into the amphotropic retroviral packaging cell line Phoenix. Retrovirus produced by the packaging cells was used to transduce the dog kidney derived cell lines MDCKI (38) and -II (39), and after 2 wk of selection with G-418, 50 clones from each transduction were picked and analyzed for the presence of cMOAT protein. For detection we used the mAb M $\mathrm{M}_{2}$-III-6 (25). This $\mathrm{mAb}$ was raised against rat cmoat, but it recognizes human cMOAT in both Western blotting and immunocytochemistry experiments with high specificity $(30,31)$. By Western blot analysis of crude membrane fractions with this antibody we identified several clones with a substantial amount of cMOAT (Fig. 1). No signal was detectable in wildtype MDCKI cells, but after prolonged exposure a weak band was observed in wild-type MDCKII cells with a slightly lower mobility than cMOAT. This might either represent canine cMOAT or another canine protein to which this $\mathrm{mAb}$ cross reacts.

Immunolocalization of cMOAT in MDCKII cells. The subcellular distribution of cMOAT was determined in MDCKIIMOAT17 cells, which gave the strongest signal in Western blots. Cells were grown to confluency on microporous membrane filters to establish optimal polarization and cMOAT was visualized by indirect immunolocalization using confocal laser scanning microscopy (CLSM). Clear staining was observed in $\sim 50 \%$ of the cells (Fig. $2 A$ ), whereas MDCKII wild-type cells stained only very weakly (Fig. $2 B$ ). Examination of the MDCKII-MOAT17 cells at a plane perpendicular to the membrane filter showed that cMOAT immunostaining was confined to the apical plasma membrane, although some intracellular staining was observed in some cells as well (Fig. $2 A$ ). To verify that the apical staining of cMOAT was due to localization in the plasma membrane and not in a subapical compartment, we performed immunoelectron microscopy. Ultrathin frozen sections of MDCKII-MOAT17 and parental cells were cut per-
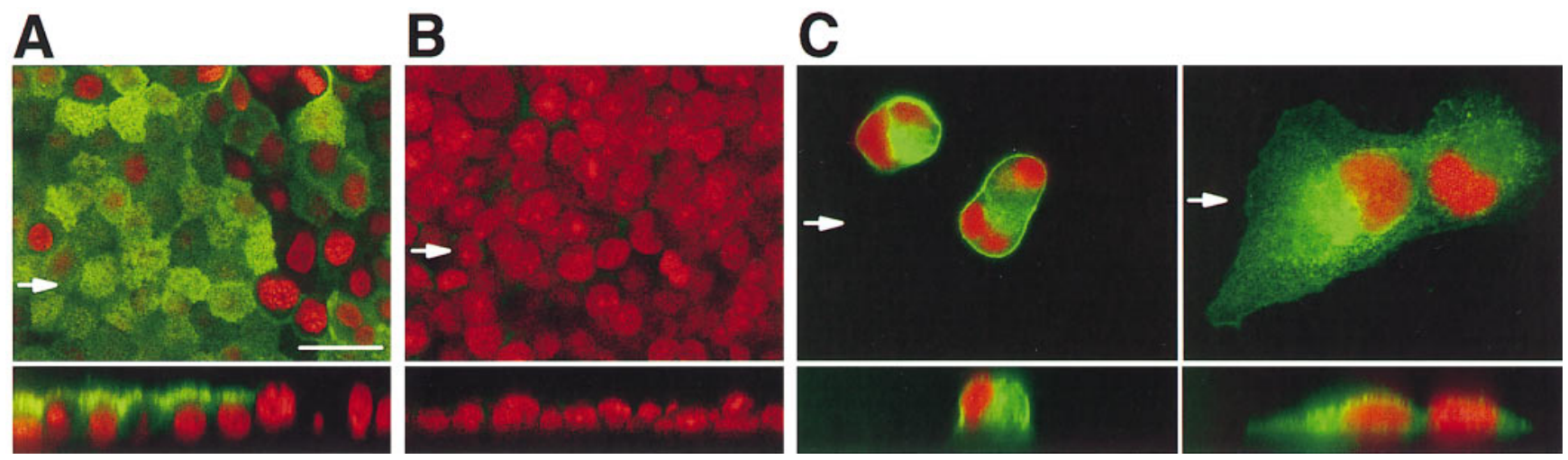

Figure 2. Immunolocalization of cMOAT in MDCKII monolayers by confocal laser-scanning microscopy. cMOAT was detected by indirect immunofluorescence (FITC; green signal) with $\mathrm{mAb} \mathrm{M}_{2}$-III-6. Nucleic acids were detected using propidium iodide (red signal). The upper part of each panel shows the top view of the monolayer. The lower part shows an optical section perpendicular to the plane of the cell layer. $(A)$ Confluent MDCKII-MOAT17 cells; $(B)$ confluent MDCKII wild-type cells; $(C)$ incubation as in $A$, but MDCKII-MOAT17 cells were seeded at a 1:20 dilution and incubated with antibodies as in $A$ after culturing overnight. Bar, $25 \mu \mathrm{m}$. 
A
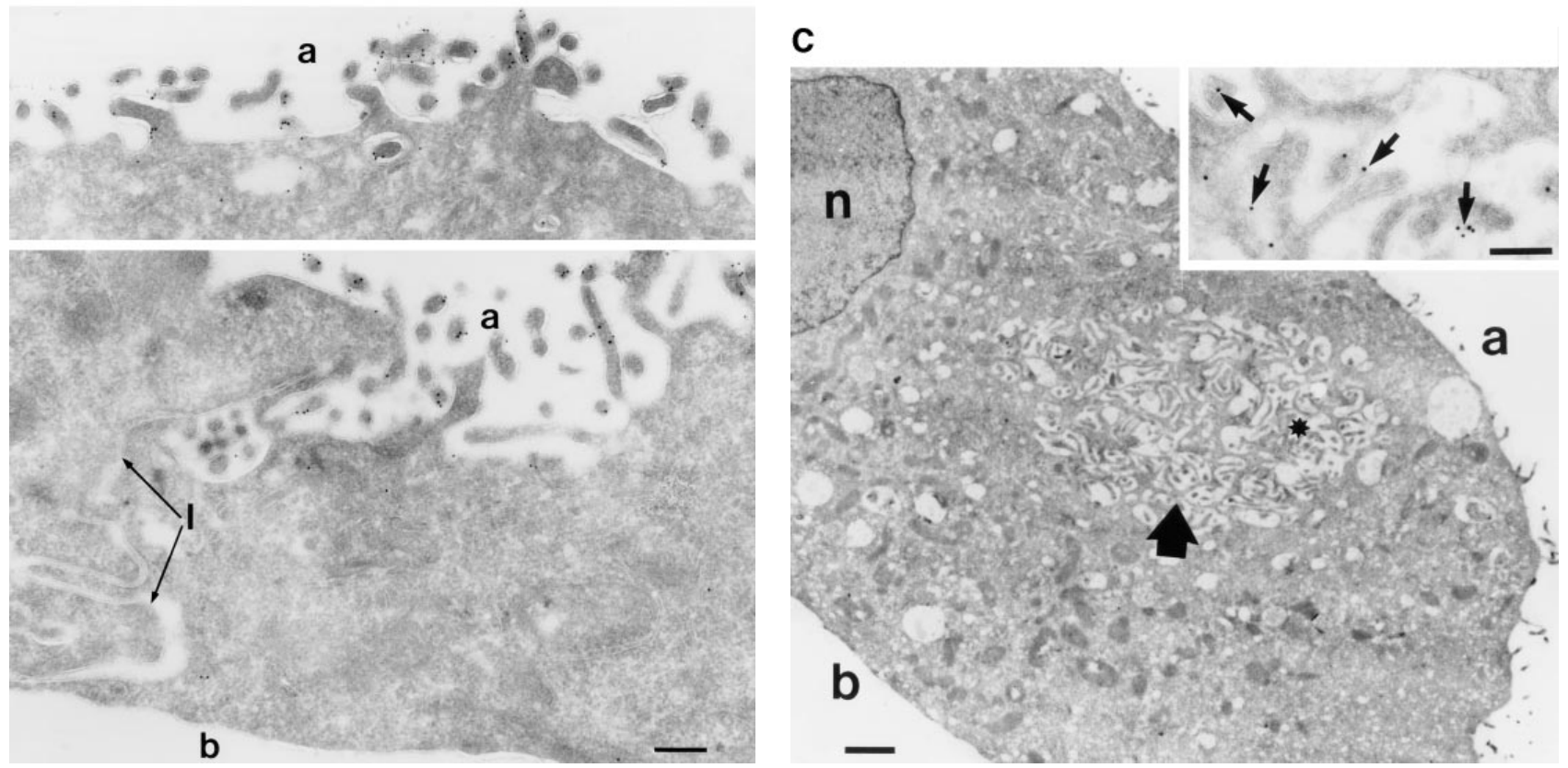

B

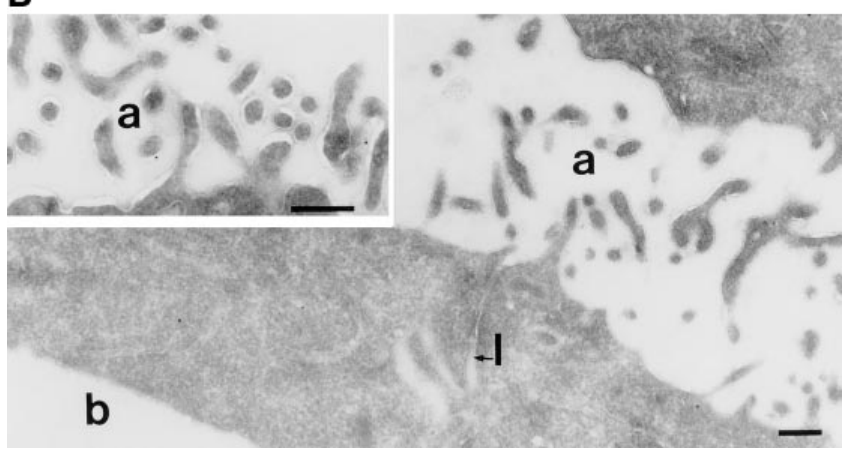

Figure 3. Detection of cMOAT in ultrathin cryosections of MDCKII cells by immunoelectron microscopy. (A) Section of MDCKIIMOAT17 cells labeled with $\mathrm{mAb} \mathrm{M}_{2}$-III-6 to detect cMOAT, showing the apical $(a)$, lateral $(l)$, and basal surface $(b)$. Most gold particles are present over the microvilli forming the apical membrane. (B) Same as $A$, but with MDCKII parental cells. Weak labeling of the apical surface is present. Bars, $300 \mathrm{~nm}$. (C) MDCKII-MOAT17 cells were seeded at a low density and processed as in $A$. A cell with an intracellular structure with many microvilli (thick arrow) is shown. The surface originally facing the culture flask $(b)$, the surface facing the medium $(a)$, and the nucleus $(n)$ are indicated. Bar, $1 \mu \mathrm{m}$. (Inset) Higher magnification of the vacuolar region marked with an asterisk, showing that the microvilli are labeled with gold (arrows). Bar, $200 \mathrm{~nm}$.

pendicular to the monolayer and incubated with $\mathrm{mAb}_{2}$-III-6, followed by rabbit anti-mouse IgG linked to $10 \mathrm{~nm}$ gold particles. Most signal was detected in the microvilli of the apical membrane (Fig. $3 \mathrm{~A}$ ), whereas the basolateral plasma membrane was hardly labeled. Some apical staining was also observed in the MDCKII parental cells (Fig. $3 B$ ). Comparison of the absolute amounts of gold particles counted in MDCKIIMOAT17 and parental cells demonstrated that the numbers of intracellular gold particles were comparable between the two cell lines, whereas about 10 -fold more gold particles were found in the apical membrane of the MDCKII-MOAT17 cells (Table I). We conclude that most of the cMOAT molecules in the MDCKII-MOAT17 cells are localized in the apical membrane.

A very different staining pattern than in polarized cells was obtained with the Phoenix packaging cell line and COS cells transfected with $c M O A T$ cDNA. In these nonpolarized cells cMOAT was hardly detectable in the plasma membrane, and nearly all fluorescence was intracellular (data not shown). This suggests that cMOAT is only routed towards the plasma membrane in polarized cells. To test this hypothesis we seeded MDCKII-MOAT17 cells at low density and visualized cMOAT by CLSM after one day of culturing. Two types of cells were observed: $(a)$ cells with a round morphology, which showed both staining at or in the plasma membrane and strong intracellular staining (Fig. $2 C$, left panel), and (b) many relatively flat cells with a strong fluorescence signal mainly confined to a

Table I. Absolute Amounts of Gold Particles Detected in MDCKII-MOAT17 and MDCKII Parental Cells

\begin{tabular}{|c|c|c|c|c|c|c|c|}
\hline Cell line & $\begin{array}{c}\text { Apical } \\
\text { plasma membrane }\end{array}$ & $\begin{array}{c}\text { Lateral } \\
\text { plasma membrane }\end{array}$ & $\begin{array}{c}\text { Basal } \\
\text { plasma membrane }\end{array}$ & ER & TGN & Nucleus & Total \\
\hline MDCKII-MOAT17 & 817 & 37 & 9 & 32 & 14 & 54 & 963 \\
\hline MDCKII & 84 & 32 & 5 & 38 & 7 & 68 & 234 \\
\hline
\end{tabular}

Gold particles counted in 15 cell profiles from each cell line are shown. From the MDCKII-MOAT17 cell line cells were selected which showed positive staining. These amounted to $\sim 30 \%$ of the total population. 

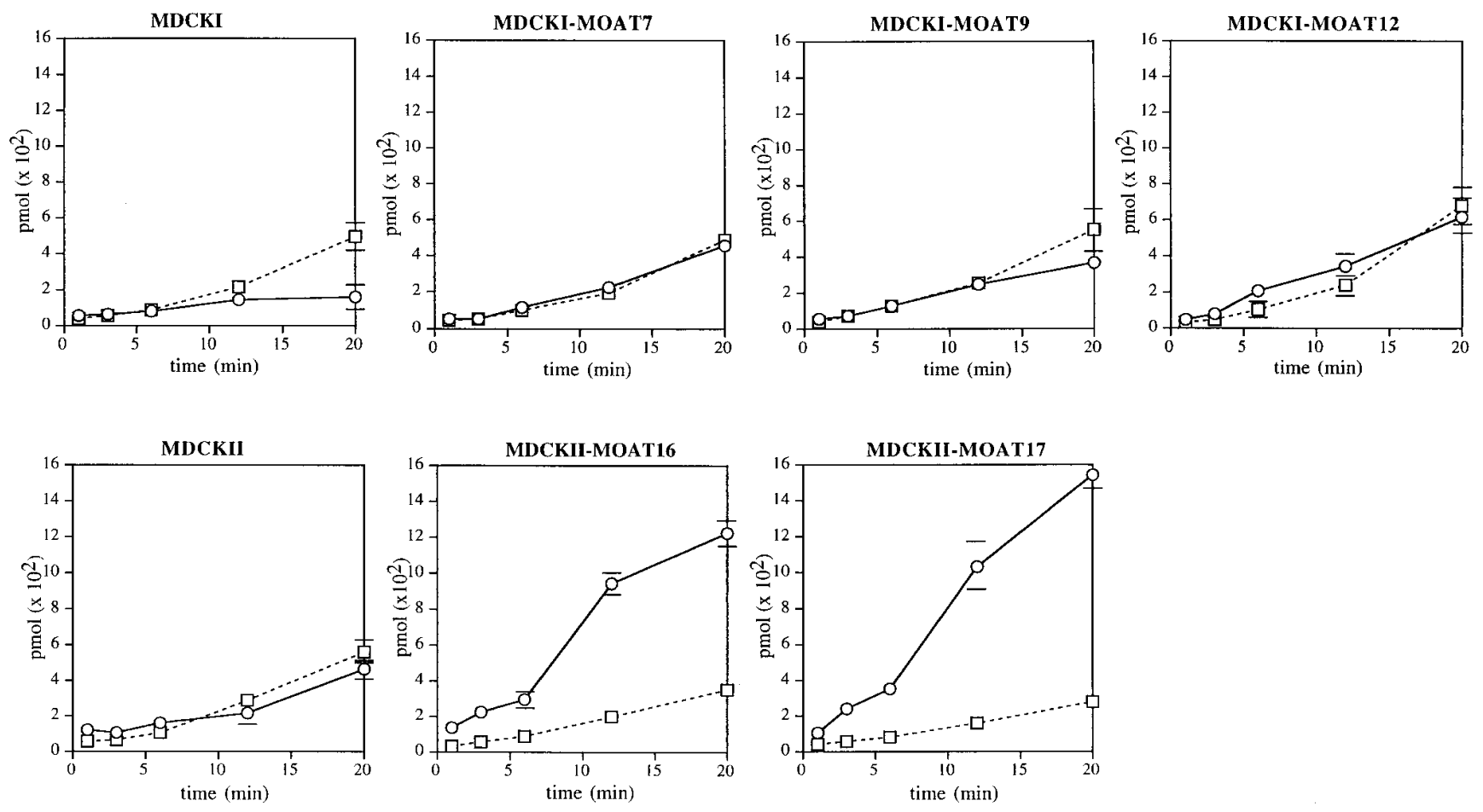

Figure 4. Transport of $\left[{ }^{14} \mathrm{C}\right] \mathrm{DNP}-\mathrm{GS}$ from MDCKI- and MDCKII-derived clones grown in monolayers. Cells were incubated at room temperature with $\left[{ }^{14} \mathrm{C}\right] \mathrm{CDNB}(2 \mu \mathrm{M} ; \mathrm{t}=0)$ in both the apical and basal compartment. Samples were taken at $\mathrm{t}=1,3,6,12$, and $20 \mathrm{~min}$ from both compartments and extracted with ethyl acetate. The amount of $\left[{ }^{14} \mathrm{C}\right] \mathrm{DNP}-\mathrm{GS}$ transported (in picomole per $2 \mathrm{ml}$ ) was measured and plotted. All experiments were done in duplicate and repeated at least twice. Continuous line and circles, transport to the apical compartment; dashed lines and squares, transport to the basal compartment.

region adjacent to the nucleus (Fig. $2 C$, right panel). Inspection of cells growing at low density by immunoelectron microscopy demonstrated that these cells did not form tight junctions, confirming that they were not polarized. Many cells were observed that contained an extensive network of microvilli, which was present both intracellularly and on the cell surface, suggesting that these cells were endocytosing their apical membrane. In other cells endocytosis of the apical membrane seemed to be complete: some gold particles were detected in the plasma membrane, in the endoplasmic reticulum and in the trans-Golgi network, but most gold particles were found in large microvilli-rich intracellular regions (Fig. $3 C$ ).

Export of dinitrophenyl glutathione and prostaglandin $A_{1}$ glutathione by MDCK-MOAT cells. We have shown before that transport by an organic anion transporter, such as MRP1, can be studied in polarized cells using $\left[{ }^{14} \mathrm{C}\right] \mathrm{CDNB}$ (21). This hydrophobic compound rapidly diffuses into cells and is conjugated to GSH by cellular glutathione $S$-transferases (GSTs; reference 43$)$. The resulting hydrophilic $\left[{ }^{14} \mathrm{C}\right] \mathrm{DNP}-\mathrm{GS}$ can only leave the cell by carrier-mediated transport. Transport of $\left[{ }^{14} \mathrm{C}\right] \mathrm{DNP}-\mathrm{GS}$ across the apical and the basolateral membrane can be distinguished by growing cells as a monolayer on microporous membrane filters. Using this assay we previously demonstrated that polarized epithelial LLC-PK1 cells stably transfected with MRP1 cDNA preferentially export DNP-GS towards the basolateral side via in the lateral plasma membrane localized MRP1 (21).

The $\left[{ }^{14} \mathrm{C}\right] \mathrm{DNP}-\mathrm{GS}$ export by polarized monolayers of MDCKI, MDCKII, and the $c M O A T$ expressing clones is presented in Fig. 4. Both MDCKI and MDCKII wild-type cells transport $\left[{ }^{14} \mathrm{C}\right] \mathrm{DNP}-\mathrm{GS}$. The endogenous transport to the basal compartment was comparable in both parental cell lines, whereas endogenous apical export was approximately twofold lower in MDCKI than in MDCKII cells. Apical $\left[{ }^{14} \mathrm{C}\right] \mathrm{DNP}-\mathrm{GS}$ export was substantially increased in all $c M O A T$ transfected clones, demonstrating that cMOAT causes transport in these cells. Clones with the highest amounts of cMOAT on the Western blot (i.e., MDCKII-MOAT16 and MDCKII-MOAT17, Fig. 1) gave the highest rates of apical transport. To exclude that differences in apparent transport capacity between individual clones were due to differences in endogenous GST activity, and therefore differences in conjugation capacity, we determined the total amount of $\left[{ }^{14} \mathrm{C}\right] \mathrm{DNP}-\mathrm{GS}$ retrieved from cells and medium together after $20 \mathrm{~min}$. The results presented

Table II. Accumulation and Total Synthesis of DNP-GS in MDCK-derived Cell Lines after Incubation for $20 \mathrm{Min}$ with $\left[{ }^{14} \mathrm{C}\right] \mathrm{CDNB}$

\begin{tabular}{lcc}
\hline \multicolumn{1}{c}{ Cell line } & \multicolumn{2}{c}{$\left[{ }^{14} \mathrm{C}\right]$ DNP-GS, nanomoles per $2 \times 10^{6}$ cells } \\
\hline & Intracellular & Intracellular + medium \\
MDCKI & $1.7 \pm 0.02$ & 2.3 \\
MDCKI-MOAT7 & $1.2 \pm 0.09$ & 2.2 \\
MDCKI-MOAT9 & $1.1 \pm 0.09$ & 2.1 \\
MDCKI-MOAT12 & $1.2 \pm 0.06$ & 2.5 \\
MDCKII & $1.3 \pm 0.03$ & 2.3 \\
MDCKII-MOAT16 & $0.5 \pm 0.04$ & 2.1 \\
MDCKII-MOAT17 & $0.2 \pm 0.02$ & 2.1 \\
& & \\
\hline
\end{tabular}


Table III. Inhibition of the Appearance of DNP-GS in the Medium of MDCKII Cells by Energy Depletion

\begin{tabular}{|c|c|c|c|c|c|c|}
\hline \multirow[b]{2}{*}{ Cells } & \multicolumn{3}{|c|}{ Control } & \multicolumn{3}{|c|}{ ATP-depleted } \\
\hline & Apical & Basolateral & Intracellular & Apical & Basolateral & Intracellular \\
\hline MDCKII & $18 \pm 2$ & $150 \pm 0.4$ & $3.4 \pm 0.4$ & $7 \pm 0.6$ & $34.5 \pm 14.4$ & $44.1 \pm 1.4$ \\
\hline MDCKII-MOAT17 & $114 \pm 2$ & $56.6 \pm 7.7$ & $4.9 \pm 0.2$ & $11 \pm 4$ & $10.7 \pm 4.5$ & $40.8 \pm 0.4$ \\
\hline
\end{tabular}

After preincubation for $15 \mathrm{~min}$ at $37^{\circ} \mathrm{C}$ with $\mathrm{HBSS}$ (plus glucose), or HBSS (minus glucose) plus $2 \mathrm{mM}$ deoxyglucose plus $2 \mathrm{mM} \mathrm{KCN}$ plus $20 \mathrm{mM} \mathrm{KF}$, cell monolayers were incubated with $0.6 \mu \mathrm{M}\left[{ }^{14} \mathrm{C}\right] \mathrm{CDNB}$ on both sides of the monolayer for $20 \mathrm{~min}$. Medium was collected and extracted with ethyl acetate. The experiment was performed in triplicate. Data are expressed in pmol $\left[{ }^{14} \mathrm{C}\right] \mathrm{DNP}-\mathrm{GS} \pm \mathrm{SD}$.

in Table II show that comparable amounts of $\left[{ }^{14} \mathrm{C}\right] \mathrm{DNP}-\mathrm{GS}$ were formed in all clones, but that more of this $\left[{ }^{14} \mathrm{C}\right] \mathrm{DNP}-\mathrm{GS}$ had been exported in the clones with substantial cMOAT activity than in the clones with little or no cMOAT. To assess whether the presence of DNP-GS in the apical and basal medium was a consequence of active transport, cells were subjected to energy depletion before incubation with $\left[{ }^{14} \mathrm{C}\right] \mathrm{CDNB}$. This treatment resulted in a strong decrease in the fraction of DNP-GS appearing in the medium, whereas there was a strong increase in intracellular accumulation of DNP-GS (Table III). In these experiments basolateral transport was higher than in the experiments shown in Fig. 4. This discrepancy could be due to the fact that the ATP-depletion experiment was performed in HBSS in the absence of phenol red.

It has been shown that the prostaglandin $\mathrm{A}_{1}\left(\mathrm{PGA}_{1}\right)$ is a potent inhibitor of transport mediated by MRP1 in intact cells, whereas $\mathrm{PGE}_{1}$ is not (44). This difference may be explained by the ability of $\mathrm{PGA}_{1}$, but not $\mathrm{PGE}_{1}$, to form a conjugate with GSH, resulting in $\mathrm{PGA}_{1}-\mathrm{GS}(14,42)$. We have found that this conjugate is actively transported by MRP1 (Evers, R., and P. Borst, unpublished results) and it can therefore act as a competitive inhibitor of MRP1. In vivo, the conjugation reaction between PGA $_{1}$ and GSH occurs both by GSTs and spontaneously (45). As $\mathrm{PGA}_{1}$ is an organic anion, it probably only enters the cell by a transporter (46). To investigate whether
PGA $_{1}$-GS is also a substrate for cMOAT, transport was measured in MDCKII, MDCKII-MOAT16, and MDCKIIMOAT17 cells by incubating cells with $\left[{ }^{3} \mathrm{H}\right] \mathrm{PGA}_{1}$. Intracellularly formed and exported $\left[{ }^{3} \mathrm{H}\right] \mathrm{PGA}_{1}$-GS were separated from unconjugated $\left[{ }^{3} \mathrm{H}\right] \mathrm{PGA}_{1}$ by extracting the samples with ethyl acetate (see reference 42). Although the polar $\left.{ }^{3} \mathrm{H}\right] \mathrm{PGA}_{1}$ metabolite in erythrocytes is $\mathrm{PGA}_{1}$-GS (42) and in vitro experiments with liver and kidney extracts suggest that the predominantly formed polar metabolite of $\mathrm{PGA}_{1}$ is $\mathrm{PGA}_{1}$-GS (45), we formally can not exclude that we also detect other polar metabolites than $\left[{ }^{3} \mathrm{H}\right] \mathrm{PGA}_{1}$-GS. Fig. 5 shows the presence of some polar $\left[{ }^{3} \mathrm{H}\right] \mathrm{PGA}_{1}$ metabolite transport activity towards both the apical and basolateral compartment in wild-type cells. Only low levels of intracellular radioactivity were found after 60 min (10 picomole per $2 \times 10^{6}$ cells), suggesting that the uptake of $\left[{ }^{3} \mathrm{H}\right] \mathrm{PGA}_{1}$ is rate-limiting in these cells. However, a marked increase in apical transport was found in MDCKIIMOAT16 and MDCKII-MOAT17 cells, with a concomitant drop in basolateral transport (Fig. 5). The total amount of exported polar metabolite was comparable in all three cell lines, suggesting that competition for polar $\left[{ }^{3} \mathrm{H}\right] \mathrm{PGA}_{1}$ metabolite between apical cMOAT and the basolaterally localized endogenous organic anion transporters causes the altered balance between apical and basolateral transport between wild-type and cMOAT expressing cells.
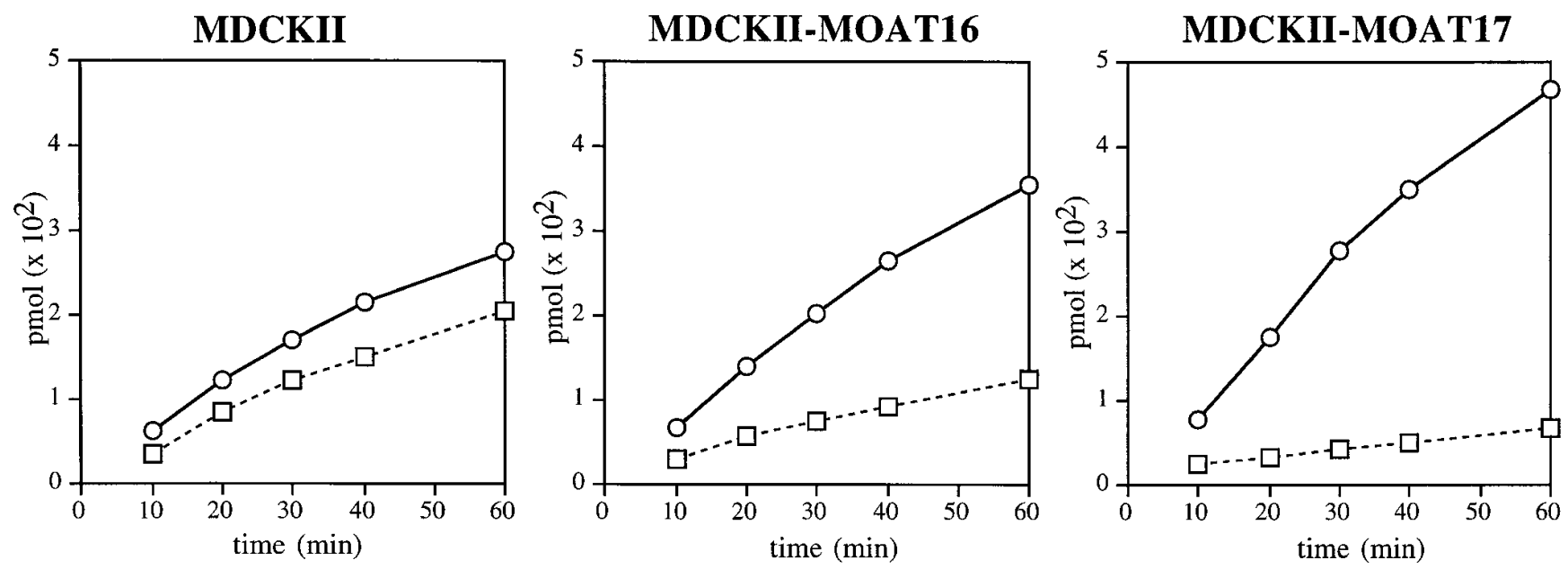

Figure 5. Transport of $\mathrm{PGA}_{1}$-GS by MDCKII monolayers. Cells were incubated at $37^{\circ} \mathrm{C}$ and $5 \% \mathrm{CO}_{2}$ with $\left[{ }^{3} \mathrm{H}\right] \mathrm{PGA} \mathrm{P}_{1}(1 \mu \mathrm{M})$ in both compartments and samples were taken at $\mathrm{t}=10,20,30,40$, and $60 \mathrm{~min}$. Samples were treated as in Fig. 3. Continuous line and circles, transport to the apical compartment; dashed line and squares, transport to the basal compartment. Experiments were performed in duplicate. Variation between measurements was within the size of symbols. 
Table IV. Effect of Inhibitors on the MOAT-mediated Export of DNP-GS by MDCKII-MOAT17 Cells

\begin{tabular}{lc}
\hline \multicolumn{1}{c}{ Inhibitor } & Percent of control \\
\hline- & 100 \\
Sulfinpyrazone $(2 \mathrm{mM})$ & $130 \pm 3$ \\
Indomethacin $(100 \mu \mathrm{M})$ & $109 \pm 4$ \\
Probenecid $(10 \mathrm{mM})$ & $83 \pm 4$ \\
Bromosulphthalein $(100 \mu \mathrm{M})$ & $84 \pm 5$ \\
\hline
\end{tabular}

Cells growing in double-well plates were incubated for $10 \mathrm{~min}$ in the presence of the inhibitor indicated. At $\mathrm{t}=02 \mu \mathrm{M}\left[{ }^{14} \mathrm{C}\right] \mathrm{CDNB}$ was added. Samples were analyzed after $20 \mathrm{~min}$ as described in Fig. 4 . The $100 \%$ value represents the amount of DNP-GS exported to the apical side of the monolayer in the absence of inhibitor. The inhibitors used did not significantly affect the total amount of DNP-GS formed after 20 min. Values are means of one typical experiment performed in duplicate \pm the variation between the measurements.

Several inhibitors are known to block transport by MRP1 $(21,44,47)$, and we tested some of these on $c M O A T$ expressing cells. Sulfinpyrazone and indomethacin inhibited the basolateral DNP-GS export activity in MDCKII wild-type cells with little effect on the apical efflux (data not shown). Apical export in the MDCKII-MOAT17 cells was not inhibited at all (Table IV). Probenecid and bromosulfophthalein preferentially inhibited the apical transport activity in wild-type cells (data not shown), but transport in the MDCKII-MOAT17 cells was only inhibited by $\sim 20 \%$ (Table IV), indicating that these compounds are inefficient inhibitors of cMOAT.

Uptake of DNP-GS and EA-GS into MDCKII-MOAT17 derived vesicles. As many of the kinetic studies with cMOAT were done with inside-out vesicles derived from liver canalicular membranes $(22,23,48,49)$, we tested whether membrane vesicles derived from $c M O A T$ transduced cells showed an increased uptake of DNP- $\left[{ }^{3} \mathrm{H}\right] \mathrm{GS}$. A mixture of inside-out and inside-in membrane vesicles was prepared from MDCKIIMOAT17 and MDCKII wild-type cells and assayed for ATPdependent DNP- $\left[{ }^{3} \mathrm{H}\right] \mathrm{GS}$ uptake. Vesicles derived from MDCKII-MOAT17 cells showed time dependent accumulation of DNP- $\left[{ }^{3} \mathrm{H}\right] \mathrm{GS}$, which continued for at least $20 \mathrm{~min}$, whereas vesicles derived from MDCKII wild-type cells accumulated DNP- $\left[{ }^{3} \mathrm{H}\right] \mathrm{GS}$ only at a low rate (Fig. $6 A$ ). The $K_{\mathrm{m}}$ value for the ATP-dependent DNP- $\left[{ }^{3} \mathrm{H}\right] \mathrm{GS}$ transport in MDCKII-MOAT17 vesicles was determined in the concentration range $0.5-4 \mu \mathrm{M}$ and yielded a value of $6.5 \mu \mathrm{M}$ (data not shown).

Membrane vesicles derived from the S1 human lung carcinoma cell line or Saccharomyces cerevisiae expressing MRP1 cDNA can accumulate the glutathione conjugate of ethacrynic acid (EA-GS; reference 13). Vesicles from MDCKII-MOAT17 cells also showed time- and ATP-dependent uptake of $\left[{ }^{14} \mathrm{C}\right]$ EA-GS (Fig. $6 \mathrm{~B}$ ). The transport rate after $16 \mathrm{~min}$ was 2.8fold higher than in MDCKII cells.

Transport of $\left[{ }^{3} \mathrm{H}\right]$ vinblastine by MDCKII-MOAT17 cells. We have shown previously that there is an increased basolateral transport of the cytostatic drug $\left[{ }^{3} \mathrm{H}\right]$ daunorubicin in LLCMRP cells, in accordance with the lateral localization of MRP1 in these cells (21). To verify whether cMOAT is able to transport anti-cancer drugs to the apical side of a monolayer, vectorial transport of daunorubicin and vinblastine was studied in MDCKII, and MDCKII-MOAT17 cells. In these experiments $\left[{ }^{3} \mathrm{H}\right]$ daunorubicin $(2 \mu \mathrm{M})$ or $\left[{ }^{3} \mathrm{H}\right]$ vinblastine $(2 \mu \mathrm{M})$ were added to either the apical or the basolateral side of the monolayer, and the accumulation of radioactivity in the opposite compartment was followed (see Methods for details). With vinblastine, but not with daunorubicin, we reproducibly found an increased apical transport in MDCKII-MOAT17 cells compared with MDCKII parental cells (Fig. 7 A). A complication of these experiments was that MDCKII parental cells already transported much more drug to the apical than to the basolateral compartment, probably due to the canine Pgp present in these cells (50). To exclude that the extra vinblastine transport measured in the MDCKII-MOAT17 cells was due to a fortuitous upregulation of Pgp in these cells, we incubated Western blots of membrane fractions with the anti-Pgp mAb C-219. No significant difference in Pgp levels was observed between the cell lines (results not shown). We then tested whether the contribution of endogenous Pgp in MDCKII cells could be inhibited by the MDR inhibitor PSC833. Böhme et al. (51) have shown that PSC833 inhibits Pgp much more effectively than cMOAT, as uptake of $\mathrm{LTC}_{4}$ (a high affinity cMOAT substrate) in isolated rat liver canalicular inside-out vesicles was

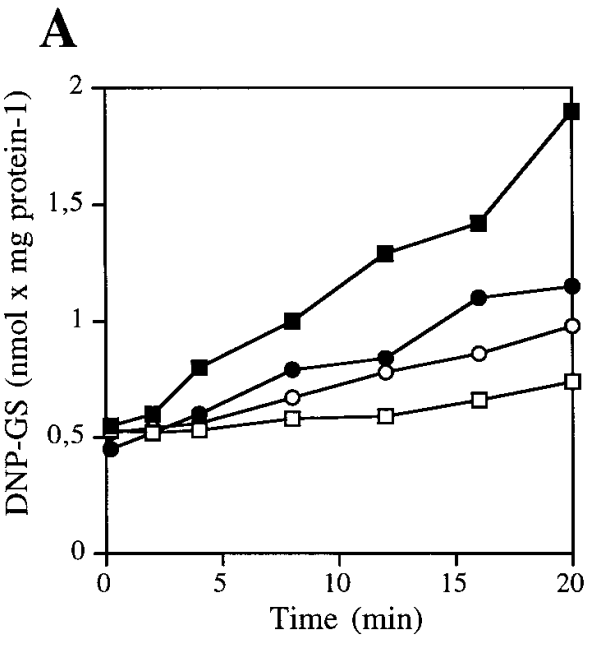

B

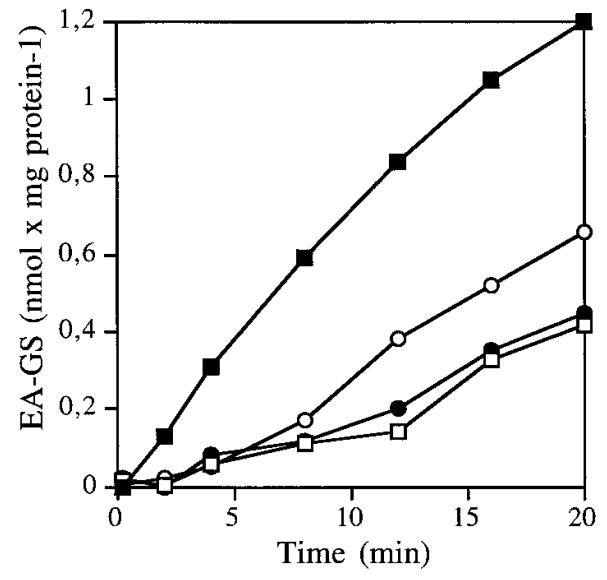

Figure 6. Time-dependent uptake of DNP- $\left[{ }^{3} \mathrm{H}\right] \mathrm{GS}$ and $\left[{ }^{14} \mathrm{C}\right] \mathrm{EA}-\mathrm{GS}$ in vesicles derived from MDCKIIMOAT17 cells. (A) Time-dependent DNP- $\left[{ }^{3} \mathrm{H}\right] \mathrm{GS}$ uptake in vesicles from MDCKII-MOAT17 (squares) and MDCKII cells (circles). Vesicles were incubated in the presence of DNP- $\left[{ }^{3} \mathrm{H}\right] \mathrm{GS}(3 \mu \mathrm{M})$ at $37^{\circ} \mathrm{C}$ as described in Methods. Samples were taken at $\mathrm{t}=0,2,4,8,12,16$, and 20 min. (B) Same as $A$, but vesicles were incubated in the presence of $\left[{ }^{14} \mathrm{C}\right]$ EA-GS $(2 \mu \mathrm{M})$ at $30^{\circ} \mathrm{C}$. Solid and open symbols represent uptake in the presence and absence of ATP, respectively. Experiments were carried out in duplicate. Similar results were obtained with two other batches of vesicles. 
A
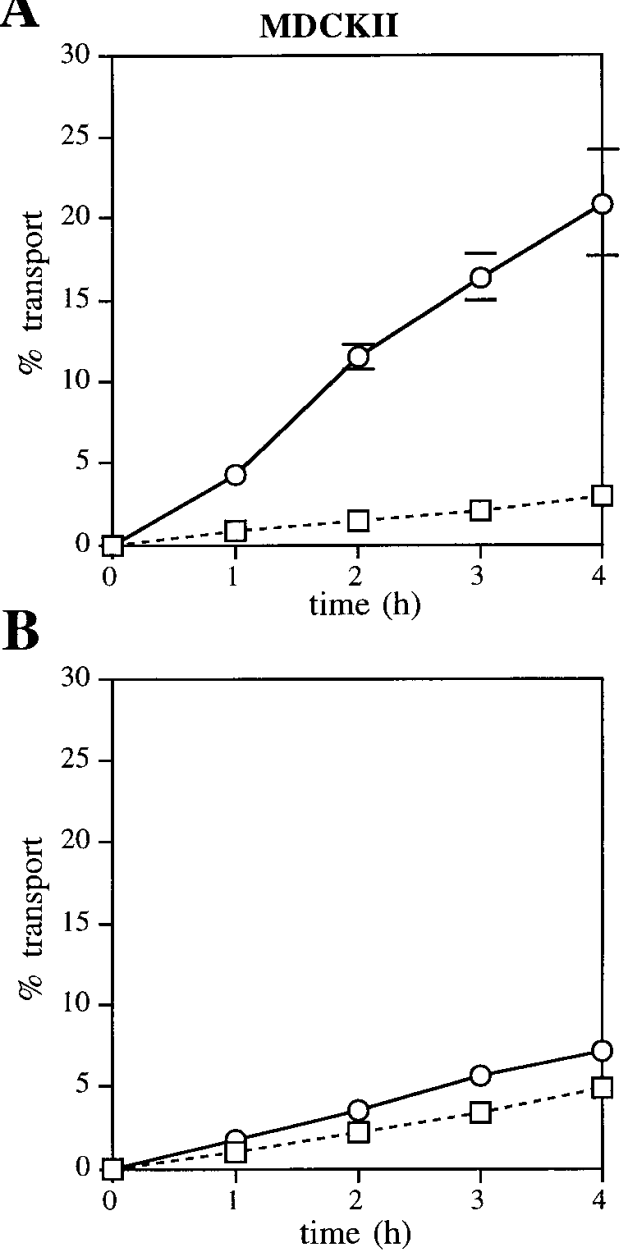
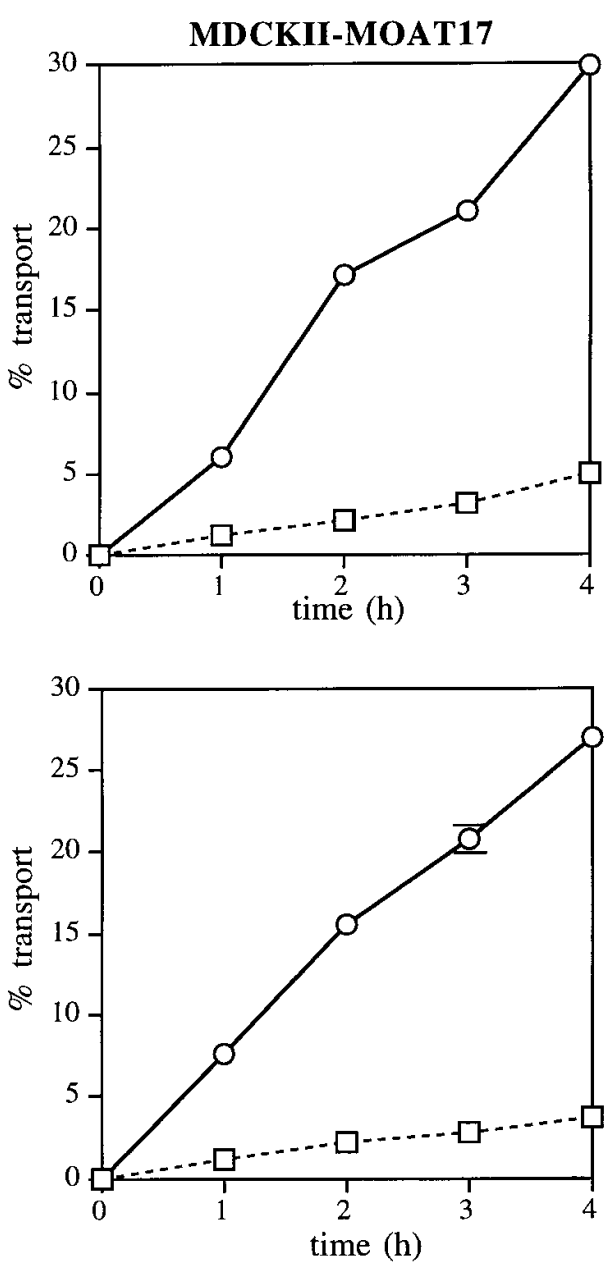

Figure 7. Transepithelial transport of $\left[{ }^{3} \mathrm{H}\right]$ vinblastine in MDCKII and MDCKII-MOAT17 monolayers. (A) At $\mathrm{t}=0\left[{ }^{3} \mathrm{H}\right]$ vinblastine $(2 \mu \mathrm{M})$ was applied either in the apical or basal compartment, and the percentage of radioactivity appearing in the opposite compartment was determined. Transport is presented as the fraction of total radioactivity added at the beginning of the experiment appearing in the opposite compartment. Samples were taken at $\mathrm{t}=1,2,3$, and $4 \mathrm{~h}$. (B) Same as $A$, but $\left[{ }^{3} \mathrm{H}\right]$ vinblastine transport was measured in the presence of $0.1 \mu \mathrm{M}$ PSC833 in both the apical and basal compartment. Continuous line and circles, translocation from the basal to the apical compartment; dashed lines and squares, translocation from the apical to the basal compartment. inhibited with a $K_{\mathrm{i}}$ of $29 \mu \mathrm{M}$, and Pgp mediated daunorubicin transport with a $K_{\mathrm{i}}$ of only $0.3 \mu \mathrm{M}$. We found that transport of vinblastine in MDCKII wild-type cells was virtually blocked at a concentration of $0.1 \mu \mathrm{M}$ PSC833, whereas transport was only slightly decreased in MDCKII-MOAT17 cells (Fig. 7 B). Even
$1 \mu \mathrm{M}$ PSC833 hardly affected vinblastine transport in the MDCKII-MOAT17 cells. This concentration of PSC833 inhibited the MDR1 Pgp mediated vinblastine transport in polarized LLC-PK1 cells stably transfected with MDR1 cDNA (32) by $70 \%$ (data not shown). To assess whether cMOAT causes
MDCKII

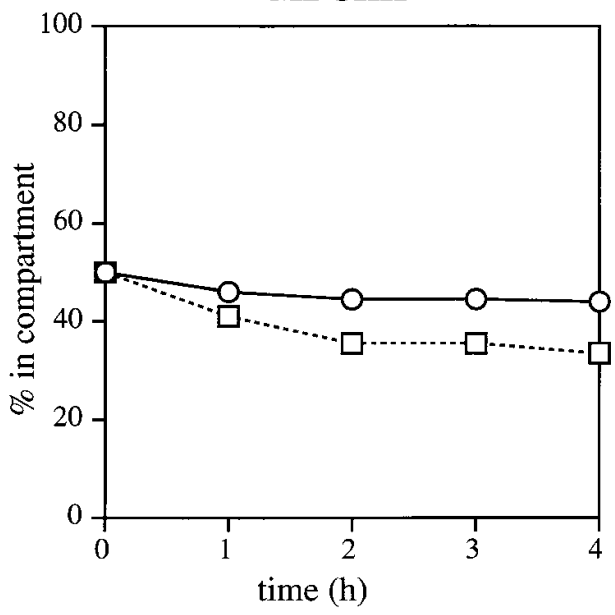

MDCKII-MOAT17

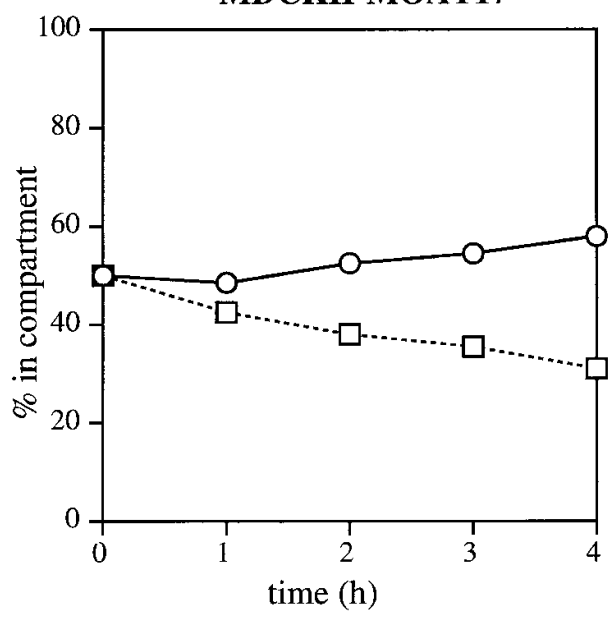

Figure 8. Uphill transport of $\left[{ }^{3} \mathrm{H}\right]$ vinblastine in MDCKII and MDCKII-MOAT17 monolayers. At $\mathrm{t}=0\left[{ }^{3} \mathrm{H}\right]$ vinblastine $(2 \mu \mathrm{M})$ in the presence of PSC833 $(0.1 \mu \mathrm{M})$ was applied to both sides of the monolayer. Percentage of radioactivity present in each compartment is presented as the fraction of total radioactivity added at the beginning of the experiment in both compartments. Samples were taken at $\mathrm{t}=1$, 2, 3, and $4 \mathrm{~h}$. Continuous lines and circles, percentage of total radioactivity in the apical compartment; dashed lines and squares, percentage of total radioactivity in the basal compartment. Experiments were carried out in duplicate and the variation between measurements was within the size of the symbols. 
uphill transport we added an equal concentration of $\left[{ }^{3} \mathrm{H}\right]$ vinblastine to both sides of the monolayer in the presence of PSC833. Fig. 8 shows that only very low transport was detectable in the parental cells, whereas transport was substantially higher in the MDCKII-MOAT17 cells and clearly occurred against a concentration gradient of vinblastine. We conclude that cMOAT causes uphill transport of vinblastine and that this transport is highly resistant to PSC833. In contrast, daunorubicin transport in both the MDCKII-MOAT17 and MDCKII cells was totally inhibited by $0.1 \mu \mathrm{M}$ PSC833, indicating that cMOAT does not transport daunorubicin (data not shown).

\section{Discussion}

In this study we show that human cMOAT is predominantly routed to the apical surface in polarized kidney MDCK cells, in accordance with its localization in hepatocytes $(30,52)$. cMOAT causes the transport of the glutathione $S$-conjugates DNP-GS and PGA $\mathrm{P}_{1}$-GS (and possibly other polar metabolites) to the apical side of a cell monolayer and vesicles derived from these cells are able to actively accumulate DNP-GS and EAGS. Although these results suggest that expression of $c M O A T$ results in an active transporter and that cMOAT does not require other liver specific proteins for transport activity, we formally can not exclude that cMOAT functions in conjunction with other proteins that are present in both liver and kidney cells. Besides the transport of glutathione $S$-conjugates, we demonstrate that cMOAT causes transport of the amphipathic anti-cancer drug vinblastine. This raises the possibility that cMOAT is another ABC-transporter that potentially could be involved in multi-drug resistance in mammalian cells. Our transport studies show that cMOAT causes transport of vinblastine (Fig. 7, $A-B$; Fig. 8), whereas it does not cause transport of daunorubicin. Vinca alkaloids are not known to be converted into negatively charged conjugates, and it is not yet clear how organic anion transporters, such as MRP1 or cMOAT, transport these compounds. Evidence that GSH is a prerequisite for MRP1-mediated MDR in intact cells was obtained by depleting cells of GSH, which resulted in the loss of resistance to vincristine $(53,54)$. Loe et al. (12) showed that high GSH concentrations are required for MRP1-mediated vincristine uptake into vesicles. Furthermore, direct binding of GSH to MRP1 was shown in a vanadate induced trapping experiment (55). It is not known, however, whether vincristine is transported as a short lived complex with GSH, cotransported with GSH, or whether glutathione is only required allosterically $(6,54)$.

Ishikawa (14) has proposed that a GS-X pump might be involved in the removal of cisplatin from the cell as a glutathione $S$-conjugate. Indeed cisplatin forms a complex with glutathione (56), and a HL-60 leukemia cell line has been described which induced $M R P 1$ expression upon exposure to cisplatin (57). However, cell lines transfected with MRP1 cDNA are not cisplatin resistant $(58,59)$. To investigate a possible role of cMOAT in cisplatin resistance, Kool et al. (31) examined a large set of drug resistant cell lines for the (over)expression of $c M O A T$. Upregulation of cMOAT was detected in several cisplatin resistant cell lines, but also expression levels of other genes were altered in these selected cells. To verify whether cMOAT is responsible for cisplatin resistance, specific inhibitors would be helpful. Several compounds have been identified which are able to inhibit MRP1-mediated transport $(21,44,47)$, but cMOAT is at best inhibited inefficiently by these compounds (Table IV). We are screening for other inhibitors that are more suitable to determine whether cMOAT contributes to drug resistance.

Initial attempts to study the transport characteristics of cMOAT were hampered by the fact that the protein was mainly localized intracellularly. Some rat cmoat-mediated DNP-GS transport activity was demonstrated by transiently transfecting the cDNA in COS cells (28), but most of the protein produced was present intracellularly (Oude Elferink, R.P.J., and C.C. Paulusma, unpublished data). We also find that stable overexpression of $c M O A T \mathrm{cDNA}$ in nonpolarized cells results in the intracellular accumulation of cMOAT. This was observed in MDCK cells before they form monolayers (Figs. $2 C$ and $3 C$ ), but also $\mathrm{S} 1$ nonsmall lung cancer cells expressing $c M O A T$ cDNA only contain cMOAT intracellularly (Kool, M., and P. Borst, unpublished data). Experiments are in progress to identify the intracellular compartment(s) in which cMOAT is accumulating in these cells.

\section{Acknowledgments}

We thank A. van Helvoort, S. Smith, J. Wijnholds, and R. Plasterk for critical comments on the manuscript. H. Spits and M. Heemskerk (Division of Immunology) are acknowledged for help in the retroviral transduction experiments. We thank G. van Meer (University of Amsterdam, The Netherlands) for providing the MDCK cells and P. van Bladeren and N. Cnubben (TNO Zeist, The Netherlands) for providing $\left[{ }^{14} \mathrm{C}\right] \mathrm{EA}-\mathrm{GS}$.

This work was supported in part by grants from the European Union (ERBCIPACT 930265), and The Dutch Cancer Society (NKI 92-41).

\section{References}

1. Higgins, C.F. 1992. ABC-transporters: from micro-organisms to man. Annu. Rev. Cell Biol. 8:67-113.

2. Gottesman, M.M., and I. Pastan. 1993. Biochemistry of multidrug resistance mediated by the multidrug transporter. Annu. Rev. Biochem. 62:385-427.

3. Borst, P., and M. Ouellette. 1995. New mechanisms of drug resistance in parasite protozoa. Annu. Rev. Microbiol. 49:427-460.

4. Gottesman, M.M., C.A. Hrycyna, P.V. Schoenlein, U.A. Germann, and I. Pastan. 1995. Genetic analysis of the multidrug transporter. Annu. Rev. Genet. 29:607-649.

5. Loe, D.W., R.G. Deeley, and S.P.C. Cole. 1996. Biology of the multidrug resistance protein, MRP. Eur. J. Cancer. 32A:945-957.

6. Zaman, G.J.R., and P. Borst. 1996. MRP, mode of action and role in MDR. In Multidrug Resistance in Cancer Cells. S. Gupta and T. Tsuruo, editors. John Wiley \& Sons Ltd., Chichester, UK. 95-107.

7. Jedlitschky, G., I. Leier, U. Buchholz, M. Center, and D. Keppler. 1994. ATP-dependent transport of glutathione $S$-conjugates by the multidrug resistance-associated protein. Cancer Res. 54:4833-4836.

8. Müller, M., C. Meijer, G.J.R. Zaman, P. Borst, R.J. Scheper, N.H. Mulder, E.G.E. de Vries, and P.L.M. Jansen. 1994. Overexpression of the gene encoding the multidrug resistance-associated protein results in increased ATPdependent glutathione S-conjugate transport. Proc. Natl. Acad. Sci. USA. 91: 8822-8826.

9. Leier, I., G. Jedlitschky, U. Buchholz, S.P.C. Cole, R.G. Deeley, and D. Keppler. 1994. The MRP gene encodes an ATP-dependent export pump for leukotriene $\mathrm{C}_{4}$ and structurally related conjugates. J. Biol. Chem. 45:2780727810.

10. Jedlitschky, G., I. Leier, U. Buchholz, K. Barnouin, G. Kurz, and D. Keppler. 1996. Transport of glutathione, glucuronate, and sulphate conjugate by the MRP gene-encoded conjugate export pump. Cancer Res. 56:988-994.

11. Loe, D.W., K.C. Almquist, S.P.C. Cole, and R.G. Deeley. 1996. ATPdependent 17 beta-estradiol 17-(beta-D-glucuronide) transport by multidrug resistance protein (MRP). J. Biol. Chem. 271:9683-9689.

12. Loe, D.W., K.C. Almquist, R.G. Deeley, and S.P.C. Cole. 1996. Multidrug resistance protein (MRP)-mediated transport of leukotriene $\mathrm{C}_{4}$ and chemotherapeutic agents in membrane vesicles. J. Biol. Chem. 271:9675-9682. 
13. Zaman, G.J.R., N.H.P. Cnubben, P.J. van Bladeren, R. Evers, and P. Borst. 1996. Transport of the glutathione conjugate of ethacrynic acid by the human multidrug resistance protein MRP. FEBS (Fed. Eur. Biochem. Soc.) Lett. 391:126-130.

14. Ishikawa, T. 1992. The ATP-dependent glutathione $S$-conjugate export pump. Trends Biochem. Sci. 17:463-468.

15. Jansen, P.L.M., and R.P.J. Oude Elferink. 1993. Defective hepatic anion secretion in mutant TR- rats. In Hepatic Transport and Bile Secretion: Physiology and Pathophysiology. N. Tavoloni and P.D. Berk, editors. Raven Press, New York. 721-731.

16. Keppler, D. 1992. Leukotrienes: biosynthesis, transport, inactivation, and analysis. Rev. Physiol. Biochem. Pharmacol. 121:2-30.

17. Zaman, G.J.R., C.H.M. Versantvoort, J.J.M. Smit, E.W.H.M. Eijdems, M. de Haas, A.J. Smith, H.J. Broxterman, N.H. Mulder, E.G.E. de Vries, F. Baas, and P. Borst. 1993. Analysis and expression of MRP, the gene for a new putative transmembrane drug transporter, in multidrug resistant lung cancer cell lines. Cancer Res. 53:1747-1750.

18. Burger, H.K., K. Nooter, G.J.R. Zaman, P. Sonneveld, K.E. van Wingerden, R.G. Oostrum, and G. Stoter. 1994. Expression of the multidrug resistance-associated protein (MRP) in acute and chronic leukemias. Leukemia (Baltimore). 8:990-997.

19. Cole, S.P.C., G. Bhardwaj, J.H. Gerlach, J.E. Mackie, C.E. Grant, K.C. Almquist, A.J. Stewart, E.U. Kurz, A.M.V. Duncan, and R.G. Deeley. 1992. Overexpression of a transporter gene in a multidrug-resistant human lung cancer cell line. Science. 258:1650-1654.

20. Mayer, R., J. Kartenbeck, M. Büchler, J. Jedlitschky, I. Leier, and D. Keppler. 1995. Expression of the MRP gene-encoded conjugate export pump in liver and its selective absence from the canalicular membrane in transport-deficient mutant hepatocytes. J. Cell Biol. 131:137-150.

21. Evers, R., G.J.R. Zaman, L. van Deemter, H. Jansen, J. Calafat, L.C.J.M. Oomen, R.P.J. Oude Elferink, P. Borst, and A.H. Schinkel. 1996. Basolateral localization and export activity of the human multidrug resistance-associated protein in polarized pig kidney cells. J. Clin. Invest. 97:1211-1218.

22. Ishikawa, T., M. Müller, C. Klünemann, and D. Keppler. 1990. ATPdependent primary active transport of cysteinyl leukotrienes across liver canalicular membrane. J. Biol. Chem. 365:19279-19286.

23. Nishida, T., Z. Gatmaitan, J. Roy-Chowdhry, and M. Arias. 1992. Two distinct mechanisms for bilirubin glucuronide transport by rat bile canalicular membrane vesicles. J. Clin. Invest. 90:2130-2135.

24. Oude Elferink, R.P.J., D.K.F. Meijer, F. Kuipers, P.L.M. Jansen, A.K. Groen, and G.M.M. Groothuis. 1995. Hepatobiliary secretion of organic compounds; molecular mechanisms of membrane transport. Biochim. Biophys. Acta 1241:215-268.

25. Paulusma, C., P.J. Bosma, G.J.R. Zaman, C.T.M. Bakker, M. Otter, G.L. Scheffer, R.J. Scheper, P. Borst, and R.P.J. Oude Elferink. 1996. Congenital jaundice in rats with a mutation in a multidrug resistance-associated protein gene. Science. 271:1126-1128.

26. Büchler, M., J. König, M. Brom, J. Kartenbeck, H. Spring, T. Horie, and D. Keppler. 1996. cDNA cloning of the hepatocyte canalicular isoform of the multidrug resistance protein, cMRP, reveals a novel conjugate export pump deficient in hyperbilirubinemic rats. J. Biol. Chem. 271:15091-15098.

27. Ito, K., H. Suzuki, T. Hirohashi, K. Kume, T. Shimizu, and Y. Sugiyama. 1997. Molecular cloning of canalicular multispecific organic anion transporter defective in EHBR. Am. J. Physiol. 272:G16-22.

28. Madon, J., U. Eckhardt, T. Gerloff, B. Stieger, and P.J. Meier. 1997. Functional expression of the rat liver canalicular isoform of the multidrug resistance-associated protein. FEBS (Fed. Eur. Biochem. Soc.) Lett. 406:75-78.

29. Taniguchi, K., M. Wada, K. Kohno, T. Nakamura, T. Kawabe, M. Kawakami, K. Kagotani, K. Okumura, S. Akiyama, and M. Kuwano. 1996. A human canalicular multispecific organic anion transporter (cMOAT) gene is overexpressed in cisplatin-resistant human cancer cell lines with decreased drug accumulation. Cancer Res. 56:4124-4129.

30. Paulusma, C., M. Kool, P.J. Bosma, G.L. Scheffer, F. ter Borg, R.J. Scheper, P. Borst, F. Baas, and R.P.J. Oude Elferink. 1997. A mutation in the human cMOAT gene causes the Dubin-Johnson syndrome. Hepatology. 25: 1539-1542.

31. Kool, M., M. de Haas, G.L. Scheffer, R.J. Scheper, M.J.T. van Eijk, J.A. Juijn, F. Baas, and P. Borst. 1997. Analysis of expression of cMOAT (MRP2), MRP3, MRP4, and MRP5, homologs of the multidrug resistance-associated protein gene (MRP1), in human cancer cell lines. Cancer Res. 57:3527-3547.

32. Schinkel, A.H., E. Wagenaar, L. van Deemter, C.A.A.M. Mol, and P. Borst. 1995. Absence of the mdr1a P-glycoprotein in mice affects tissue distribution and pharmacokinetics of dexamethasone, digoxin, and cyclosporin A.J. Clin. Invest. 96:1698-1705.

33. Schinkel, A.H., E. Wagenaar, C.A.A.M. Mol, and L. van Deemter. 1996. P-glycoprotein in the blood-brain barrier of mice influences the brain penetration and pharmacological activity of many drugs. J. Clin. Invest. 97: $2517-2524$.

34. Heijn, M., R.P.J. Oude Elferink, and P.L.M. Jansen. 1992. ATP-dependent multispecific anion transport system in rat erythrocyte membrane vesicles. Am. J. Physiol. 262:C104-C110.

35. Ploemen, J.H.T.M., B. van Ommen, and P.J. van Bladeren. 1990. Inhibi- tion of rat and human glutathione $S$-transferase isoenzymes by ethacrynic acid and its glutathione conjugate. Biochem. Pharmacol. 40:1631-1635.

36. Ploemen, J.H.T.M., A. van Schanke, B. van Ommen, and P.J. van Bladeren. 1994. Inhibition of rat and human glutathione $S$-transferase isoenzymes by ethacrynic acid and its glutathione conjugate. Cancer Res. 54:915-919.

37. Anderson, N.H. 1969. Dehydration of prostaglandins: study by spectroscopic method. J. Lipid Res. 10:320-325.

38. Fuller, S., C.-H von Bonsdorff, and K. Simons. 1984. Vesicular stomatitis virus infects and matures only through the basolateral surface of the polarized epithelial cell line, MDCK. Cell. 38:65-77.

39. Louvard, D. 1980. Apical membrane aminopeptidase appears at site of cell-cell contact in cultured kidney epithelial cells. Proc. Natl. Acad. Sci. USA 77:4132-4136.

40. Bengal, E., L. Ransone, R. Scharfman, R. Dwarki, S.J. Tapscott, H. Weintraub, and I.M. Verma. 1992. Functional antagonism between cJun and MyoD proteins: a direct physical association. Cell. 68:507-519.

41. Kinsella, T.M., and G.P. Nolan. 1996. Episomal vectors rapidly and stably produce high-titer recombinant retrovirus. Hum. Gene Ther. 7:1405-1413.

42. Heasley, L.E., and L.L. Brunton. 1985. Prostaglandin $A_{1}$ metabolism and inhibition of cyclic AMP extrusion by avian erythrocytes. J. Biol. Chem. 260:11514-11519.

43. Oude Elferink, R.P.J., C.T.M. Bakker, and P.L.M. Jansen. 1993. Glutathione-conjugate transport by human colon adenocarcinoma cells (Caco-2 cells). Biochem. J. 290:759-764.

44. Holló, Z., L. Homolya, T. Hegedus, and B. Sarkadi. 1996. Transport properties of the multidrug resistance-associated protein (MRP) in human tumor cells. FEBS (Fed. Eur. Biochem. Soc.) Lett. 383:99-104.

45. Chaudhari, A., M.W. Anderson, and T.E. Eling. 1978. Conjugation of 15-keto-prostaglandins by glutathione $S$-transferases. Biochim. Biophys. Acta. 531:56-64.

46. Kanai, N., R. Lu, J.A. Satriano, Y. Bao, A.W. Wolkoff, A.W. Schuster, and V.L. Schuster. 1995. Identification and characterization of a prostaglandin transporter. Science. 268:866-869.

47. Feller, N., H.J. Broxterman, D.C.R. Wähler, and H.M. Pinedo. 1995. ATP-dependent efflux of calcein by the multidrug resistance protein (MRP): no inhibition by intracellular glutathione depletion. FEBS (Fed. Eur. Biochem. Soc.) Lett. 368:385-388.

48. Kobayashi, K., Y. Sogame, H. Hara, and K. Hayashi. 1990. Mechanism of glutathione $S$-conjugate transport in canalicular and basolateral rat liver plasma membranes. J. Biol. Chem. 265:7737-7741.

49. Akerboom, T.P.M., V. Narayanaswami, M. Kunst, and H. Sies. 1991. ATP-dependent S-(2,4-Dinitrophenyl)glutathione transport in canalicular plasma membrane vesicles from rat liver. J. Biol. Chem. 266:13147-13152.

50. Horio, M., K.-V. Chin, S.J. Currier, S. Goldenberg, C. Williams, I. Pastan, M.M. Gottesman, and J. Handler. 1989. Transepithelial transport of drugs by the multidrug transporter in cultured Madin-Darby Canine Kidney cells. J. Biol. Chem. 264:14880-14884.

51. Böhme, M., M. Büchler, M. Müller, and D. Keppler. 1993. Differential inhibition by cyclosporins of primary-active ATP-dependent transporters in the hepatocyte canalicular membrane. FEBS (Fed. Eur. Biochem. Soc.) Lett. 333: 193-196.

52. Kartenbeck, J., U. Leuschner, R. Mayer, and D. Keppler. 1996. Absence of the canalicular isoform of the MRP gene-encoded conjugate export pump from the hepatocytes in Dubin-Johnson syndrome. Hepatology. 23:1061-1066.

53. Versantvoort, C.H.M., H.J. Broxterman, T. Bagrij, R.J. Scheper, and P.R. Twentyman. 1995. Regulation by glutathione of drug transport in multidrug resistant human lung tumour cell lines overexpressing MRP. Br. J. Cancer. 72:82-89.

54. Zaman, G.J.R., J. Lankelma, O. van Tellingen, J. Beijnen, H. Dekker, C.C. Paulusma, R.P.J. Oude Elferink, F. Baas, and P. Borst. 1995. Role of glutathione in the export of compounds from cells by the multidrug resistanceassociated protein. Proc. Natl. Acad. Sci. USA. 92:7690-7694.

55. Taguchi, Y., A. Yoshida, Y. Takada, T. Komano, and K. Ueda. 1997. Anti-cancer drugs and glutathione stimulate vanadate-induced trapping of nucleotide in multidrug resistance-associated protein (MRP). FEBS (Fed. Eur. Biochem. Soc.) Lett. 401:11-14.

56. Ishikawa, T., and F. Ali-Osman. 1993. Glutathione-associated cis-diamminedichloroplatinum(II) metabolism and ATP-dependent efflux from leukemia cells. J. Biol. Chem. 268:20116-20125.

57. Ishikawa, T., J. Bao, Y. Yamane, K. Akimaru, K. Frindrich, C. Wright, and M.T. Kuo. 1996. Coordinated induction of MRP/GS-X pump and gammaglutamylcysteine synthetase by heavy metals in human leukemia cells. J. Biol. Chem. 271:14981-14988.

58. Cole, S.P.C, K.E. Sparks, K. Fraser, D.W. Loe, C.E. Grant, G.M. Wilson, and R.G. Deeley. 1994. Pharmacological characterization of multidrug resistant MRP-transfected human tumor cells. Cancer Res. 54:5902-5910.

59. Zaman, G.J.R., M.J. Flens, M.R. van Leusden, M. de Haas, H.S Mülder, J. Lankelma, H.M. Pinedo, R.J. Scheper, F. Baas, H.J. Broxterman, and P. Borst. 1994. The human multidrug resistance-associated protein MRP is a plasma membrane drug-efflux pump. Proc. Natl. Acad. Sci. USA. 91:88828826. 